\title{
Cutting Mechanism of Sulfurized Free-Machining Steel
}

\author{
Junsuke Fujiwara \\ Osaka University, \\ Japan
}

\section{Introduction}

In order to improve efficiency of cutting process in production industry, development of new steel which has good machinablity is desired. The work material which has good surface roughness, easy breakable chip and small tool wear as the good machinablity is expected. And the free-machining steel was developed owning to adding elements which could make the machinablity better. Of all others, leaded free-machining steel and sulfurized free-machining steel are famous. The leaded free-machining steel and sulfurized free-machining steel are well used in the production industry. However the use of the leaded free-machining steel is limited from an environmental problem. In order to develop new environmental friendly free-machining steel, it is necessary to find out the behavior of the inclusion in the work material for the improvement of the machining performance.

There are a lot of studies about the behavior of the inclusion in the free-machining steel (Narutaki et al., 1987), (Yaguchi, 1991), (Usui et al., 1980). There are some papers about the role of the lead and the manganese sulfide which are the representative inclusions. The $\mathrm{Pb}$ inclusion acts as lubricant and reduces cutting resistance (Akazawa, 1997). As the MnS is harder than steel, the MnS acts as an internal stress concentration source when the work material reforms into a chip at the cutting edge. And the MnS produced the micro-cracks at shear deformation zone. This is the cause that the shear area became small and reduces the cutting stress (Yamamoto, 1971). Although these results are almost reasonable, we must think over the role of the inclusion again in order to produce new free-machining steel. The experiment was carried out to find out the mechanism of the sulfurized inclusion on the machinablity, using some kinds of steels which have different size of the inclusion. The observation of the deformation behavior near the cutting edge was carried out to investigate the effect of the inclusion in detail.

\section{Experimental method}

In this experiment, two kinds of the sulfurized free-machining steels (Steel A and Steel B) which have different size of the inclusion were used. Figure 1 show optical microphotographs of microstructure and size distribution of MnS in the Steel A and Steel $\mathrm{B}$, respectively. The area fraction of equivalent circle diameter of the inclusions was also shown in these figures. The steel A contains larger inclusions than the steel $\mathrm{B}$. These 
sulfurized free-machining steels contain $0.42 \% \mathrm{~S}$, and chemical compositions of these materials are almost the same as shown in Table 1 . The inclusions tend to be slender parallel to rolling direction.

In an orthogonal cutting at low speed, the cutting forces were measured. The cutting width of the work material was $2 \mathrm{~mm}$. The surface of work materials was polished to observe deformation of the inclusions. An orthogonal cutting was performed using table feeding system of a horizontal milling machine as shown in Fig. 2. Table 2 shows cutting conditions in the orthogonal cutting. The cutting speed was $16 \mathrm{~mm} / \mathrm{min}$ and the depth of cut was $0.1 \mathrm{~mm}$. The tool material was high speed steel and its rake angle was 10 degree.
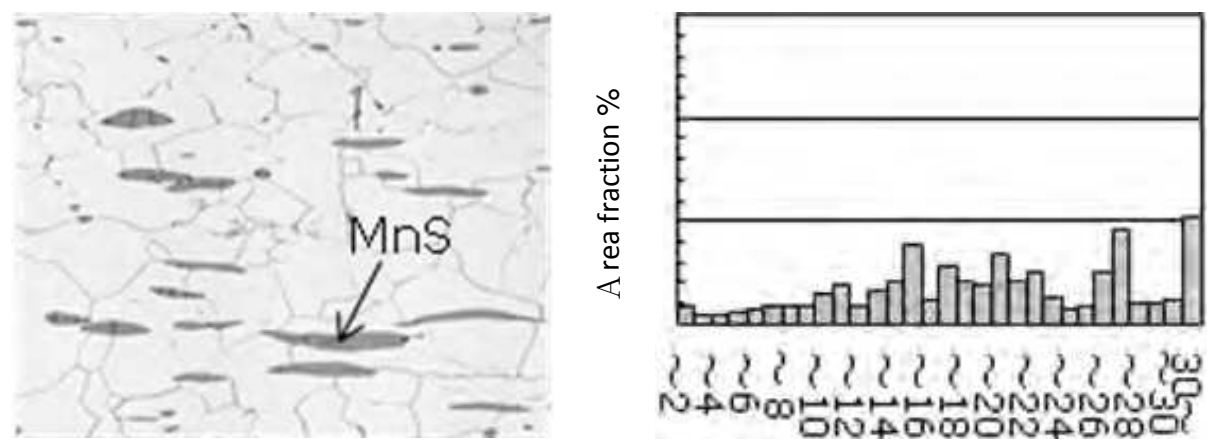

(a) Steel A

Equivalent circle diameter $\mu \mathrm{m}$
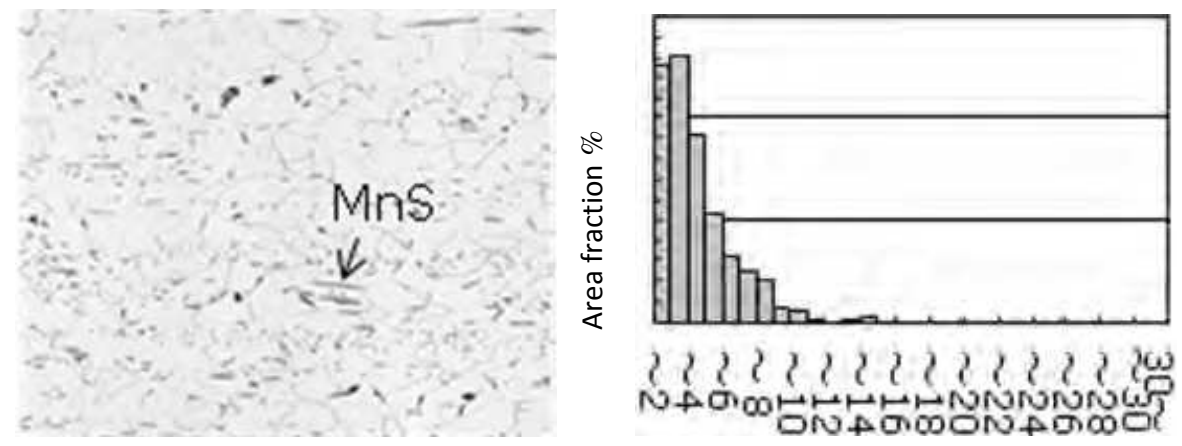

(b) Steel B

Equivalent circle diameter $\mu \mathrm{m}$

Fig. 1. Optical micrographs of microstructure and size distribution of MnS

\begin{tabular}{|c|c|c|c|c|c|c|}
\hline Mass \% & C & Si & Mn & S & Al & $\mathrm{O}_{2}$ \\
\hline Steel A & 0.03 & 0.01 & 1.44 & 0.42 & 0.001 & 0.0175 \\
\hline Steel B & 0.03 & 0.01 & 1.7 & 0.43 & 0.001 & 0.0044 \\
\hline
\end{tabular}

Table 1. Chemical compositions of work materials 


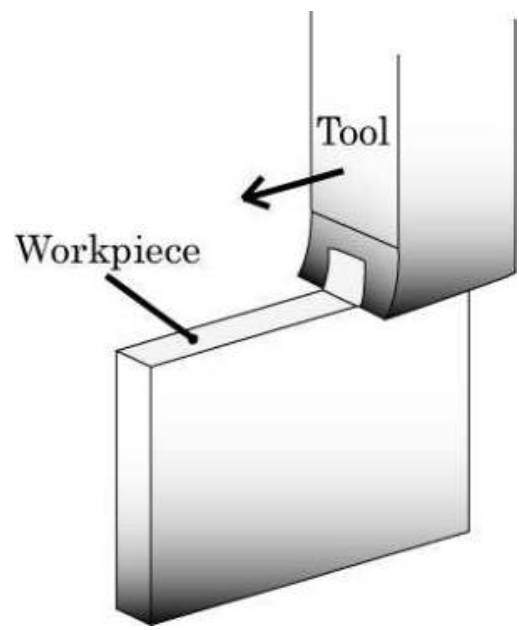

Fig. 2. Method of orthogonal cutting

\begin{tabular}{|c|c|}
\hline Cutting speed & $0.016 \mathrm{~m} / \mathrm{min}$ \\
\hline Depth of cut & $0.1 \mathrm{~mm}$ \\
\hline Tool & SHK4 \\
\hline Rake angle & $10^{\circ}$ \\
\hline Clearance angle & $17^{\circ}$ \\
\hline
\end{tabular}

Table 2. Cutting conditions in orthogonal cutting

\section{Experimental results and discussions}

\subsection{Orthogonal cutting}

The Cutting forces were measured in the orthogonal cutting. These results are shown in Fig. 3. On the whole, the cutting force in the Steel A was bigger than that in the Steel B. The cutting force in the Steel A was more stable than that in the Steel B. This fact led smooth surface roughness.

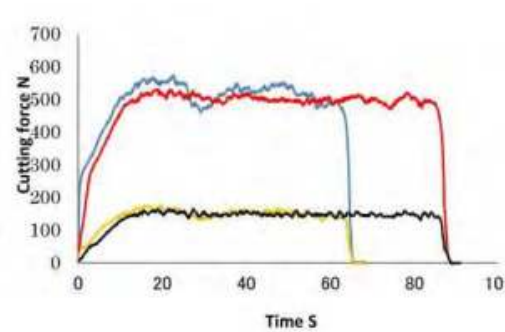

(a) Steel A

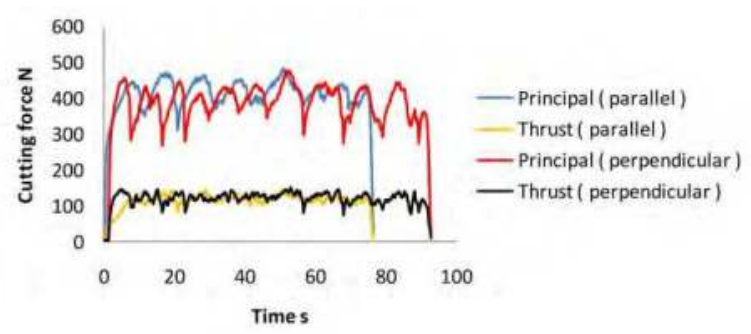

(b) Steel B

Fig. 3. Cutting forces in orthogonal cutting 
In order to investigate the flow state of around the shear zone, a quick stop test was carried out during the orthogonal cutting. Figure 4 shows the enlarged photographs around the shear zone. In case of the Steel A, the large crack parallel to the shear plane was found. In case of Steel B, the chip is thin, and there are small cracks near the rake face.

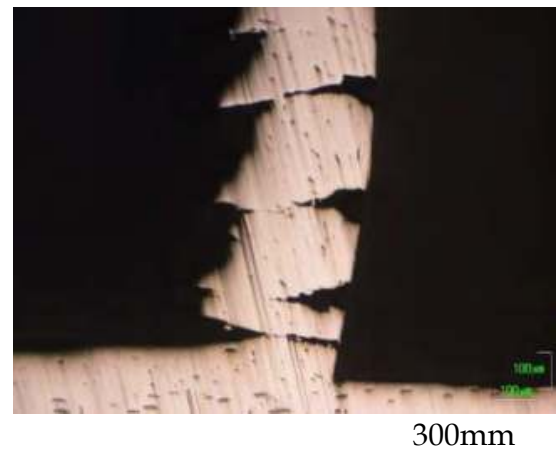

(a) Steel A

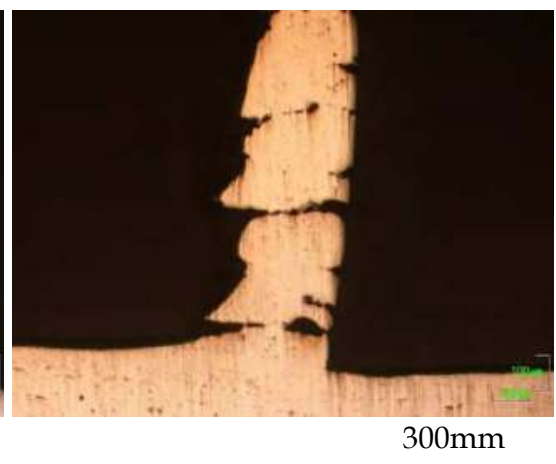

(b) Steel B

Fig. 4. Microphotographs of partially formed chip

\subsection{Micro-cutting in SEM}

A small orthogonal cutting equipment as shown in Fig. 5 was mounted into the Scanning Electrical Microscope (SEM) (Iwata 1977). The deformation behavior around the shear zone was observed in detail with the SEM. An example of the micro-cutting in SEM is also shown in this figure. The cutting speed was $0.27 \mathrm{~mm} / \mathrm{s}$ and the depth of cut was $20-50 \mu \mathrm{m}$. Table 3 shows the cutting conditions. The work material was cut from the test piece as shown in Fig.6.

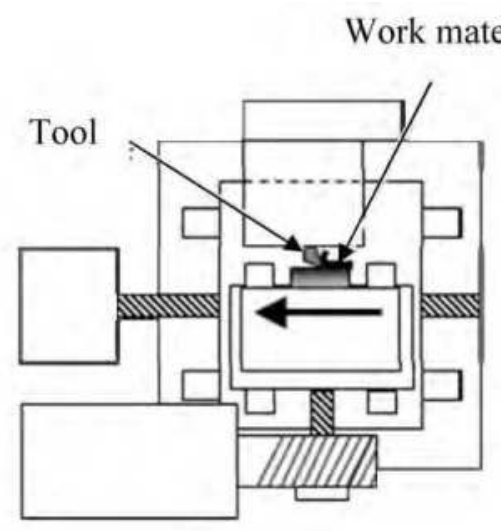

(a) Cutting equipment

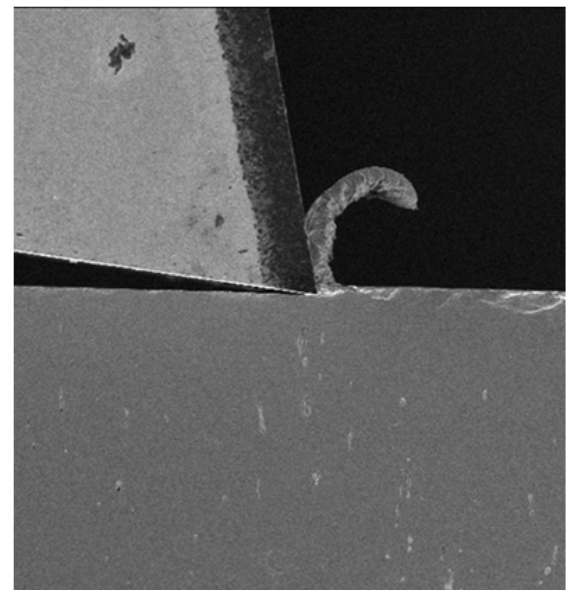

(b) Micro-cutting

Fig. 5. Cutting equipment in SEM and micro-cutting 


\begin{tabular}{|c|c|}
\hline Cutting speed & $0.27 \mathrm{~mm} / \mathrm{s}$ \\
\hline Depth of cut & $20 \sim 50 \mu \mathrm{m}$ \\
\hline Tool & SKH4 \\
\hline Rake angle & $6^{\circ}$ \\
\hline Clearance angle & $3^{\circ}$ \\
\hline
\end{tabular}

Table 3. Cutting conditions in SEM

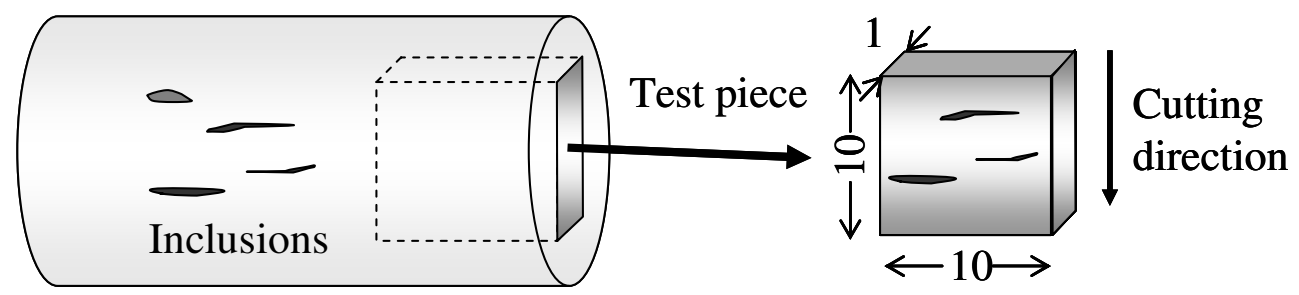

Fig. 6. Work material for micro-cutting in SEM

Figure 7 shows the sequential photographs during cutting of the Steel A. As the Steel A has the spindle shaped inclusions, the inclusion MnS which was extended perpendicular to the cutting direction can be found. This inclusion turned in counterclockwise and broke to several pieces around the shear zone. These pieces create voids around them, and flowed to the chip in the direction parallel to the shear plane. As shown in this figure, the void was formed at the upper of the inclusion and the micro-crack was formed along the primary shear plane.

Figure 8 shows the sequential photographs during cutting of the Steel B. The inclusion of higher aspect ratio than that in the Steel A can be found. As the Steel B had long slender inclusions, this inclusion broke into smaller pieces than that in the Steel A. These pieces create very small voids between them. The inclusions in the Steel B are well dispersed, so these very small voids are created at various places in the work material. It causes the reduction of the cutting force.

\subsection{Image analysis for stress distribution}

It is very important to know strain and stress distribution in shearing zone. The sequential images could be taken during micro-cutting in SEM. Using with image processing, the strain increase and stress distribution around MnS can be calculated. That is to say, as comparison with two sequential SEM images after micro movement of the tool, the displacement within observed zone could be measured by tracing a same point. Moreover the strain increase and stress distribution could be calculated from the displacement.

In order to measure the displacement from the sequential SEM images, PIV (Particle Image Velocimetry) method was used (Raffel etal., 2007). The moving distance was calculated from gray level pattern between SEM image $A$ at $t$ in time and SEM image $B$ at $t+\triangle t$ in time as shown in Fig.9. 


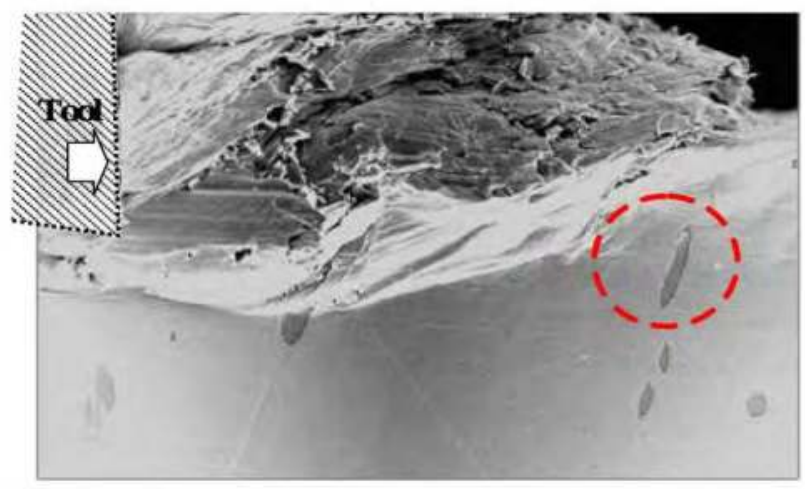

(a)

\section{$\stackrel{\longleftarrow}{20 \mu \mathrm{m}}$}

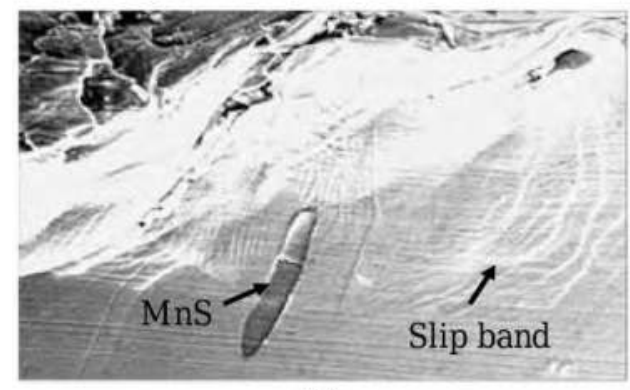

(b)

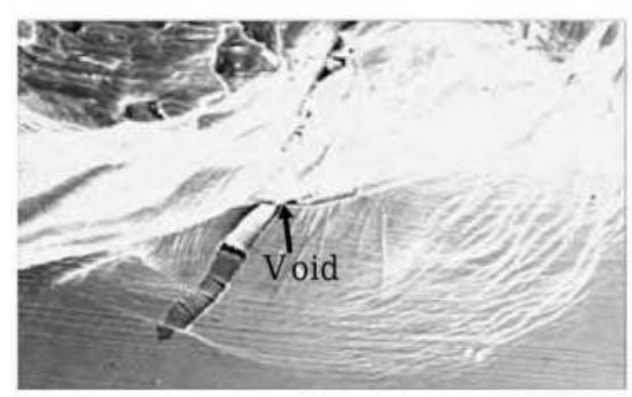

(c)

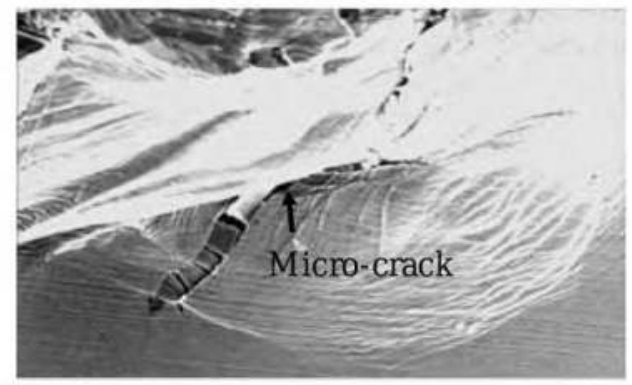

(d)

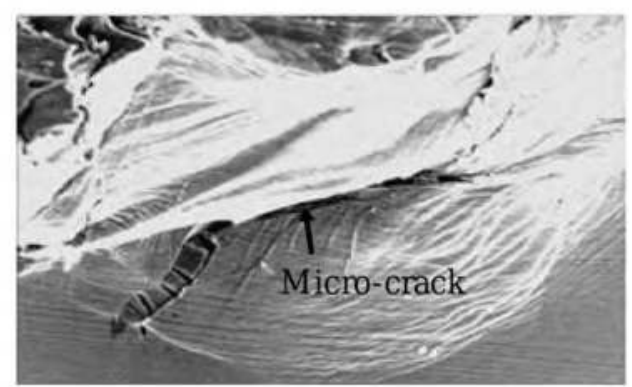

(e)

$$
40 \mu \mathrm{m}
$$

Fig. 7. Deformation behavior of large spindle shaped MnS inclusion (Steel A) 


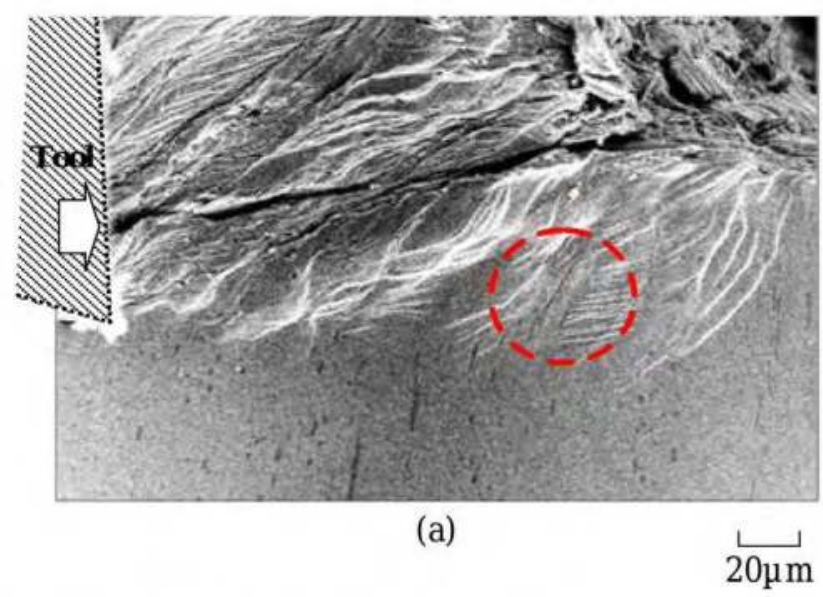

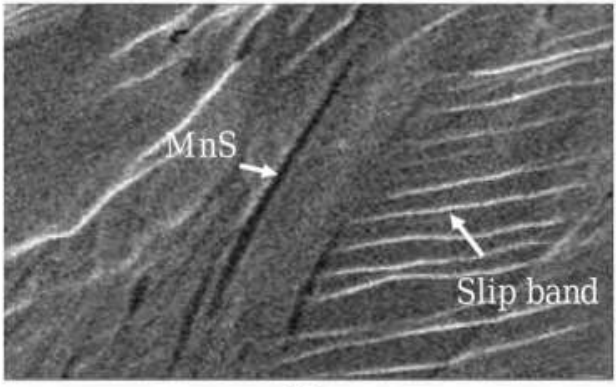

(b)

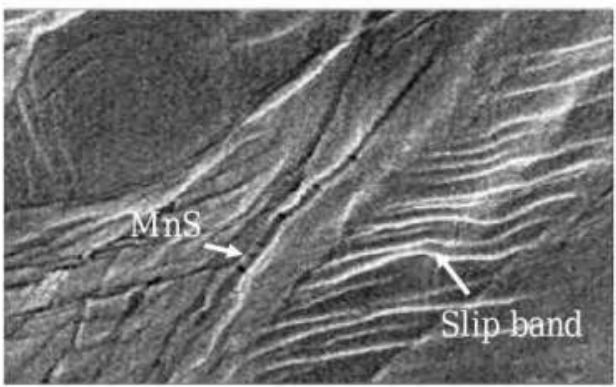

(c)

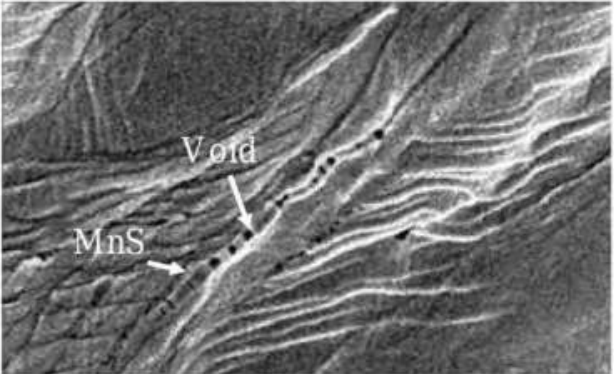

(d)

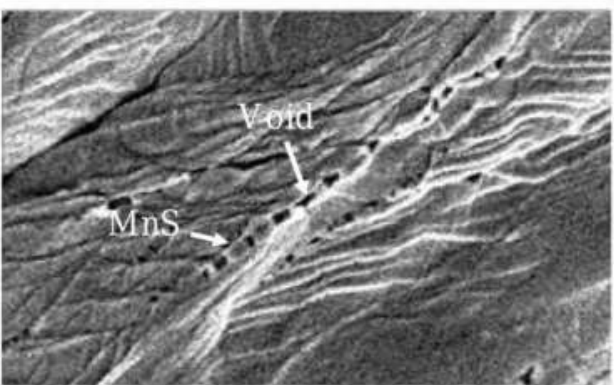

(e)

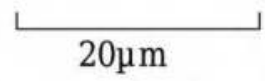

Fig. 8. Deformation behavior of long slender MnS inclusion (Steel B) 
The strain and stress distribution was calculated from the displacement increase measured with the PIV method using with FEM as shown in Fig.10 (Usui et al., 1990). In the calculation, the mechanical properties as shown in Table 4 were used.

SEM image $\mathrm{A}$ at $\mathrm{t}$ in time

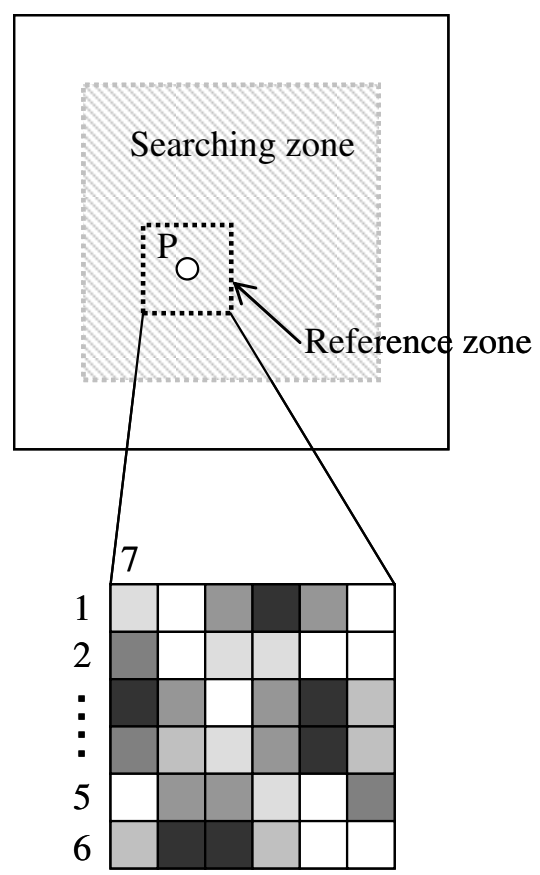

Gray value in the vicinity of point $\mathrm{P} \quad f_{i}$
SEM image $\mathrm{B}$ at $\mathrm{t}+\Delta \mathrm{t}$ in time

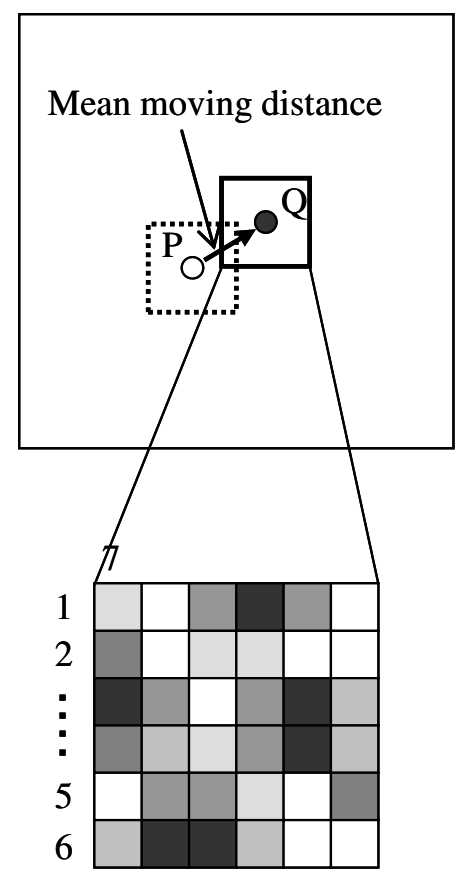

Gray value in the vicinity of point $\mathrm{Q} \quad g_{i}$

Fig. 9. Outline of correlation method in particle image velocimetry

\section{Cutting direction}

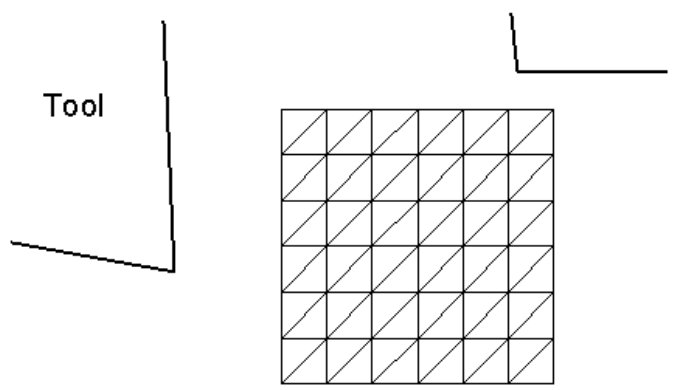

Fig. 10. Model of triangulated zone for FEM calculation 


\begin{tabular}{|c|c|c|}
\hline & Steel A & Steel B \\
\hline Yield strength MPa & 522 & 560 \\
\hline Tensile strength MPa & 525 & 563 \\
\hline Elongation \% & 13.2 & 12.0 \\
\hline Reduction of area \% & 52.1 & 48.0 \\
\hline
\end{tabular}

Table 4. Mechanical properties of work materials

The strain increase distribution was calculated from the two sequential SEM Images as shown in Fig. 7. Figure 11 shows the strain increase distribution in micro-cutting of the Steel A. The moving distance of two images was $1.8 \mu \mathrm{m}$. As shown in Fig 11 (d), the shear strain increase was large in shear zone but another large strain increase was found around MnS.

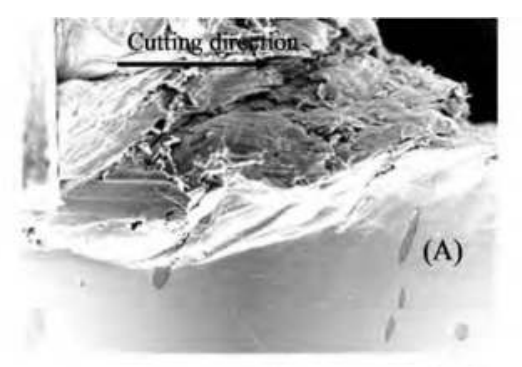

(a) SEM

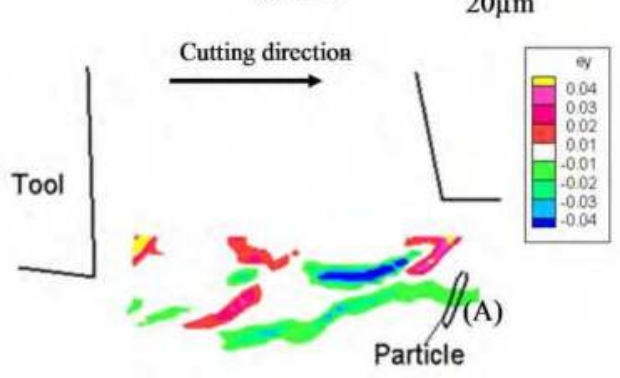

(c) $\mathrm{d} \varepsilon \mathrm{y}$

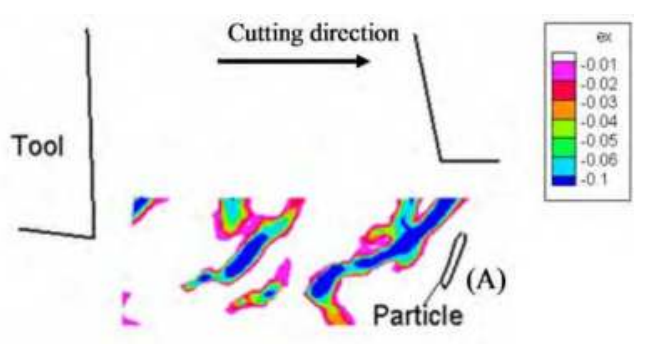

(b) $\mathrm{d} \varepsilon \mathrm{x}$

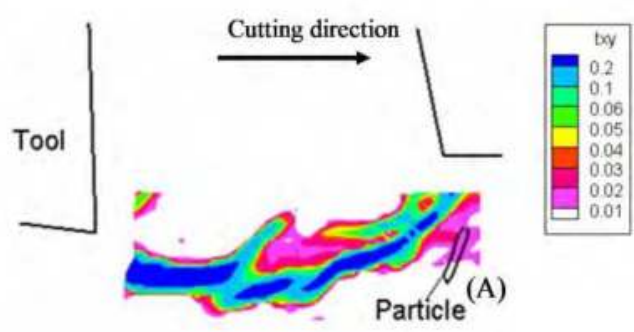

(d) $\mathrm{d} \nu \mathrm{xy}$

Fig. 11. SEM image and strain increase distribution in micro-cutting of Steel A

The stress distribution was calculated from the strain increase distribution. Figure 12 shows the stress distribution in micro-cutting of the Steel A. It shows that the stress was big at the upper of the MnS because of the stress concentration.

The strain increase distribution was calculated from the two sequential SEM Images as shown in Fig. 8. Figure 13 shows the strain increase distribution in micro-cutting of the Steel B. The moving distance of two images was $4.3 \mu \mathrm{m}$. As shown in Fig 13 (d), the strain increase along shear zone was large in and no large strain increase was found around MnS. 


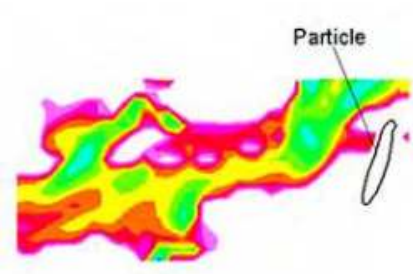

(a) $\sigma \mathrm{x}$

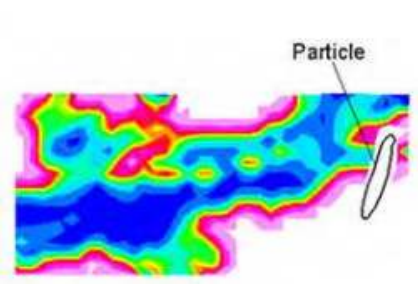

(c) $\tau \mathrm{xy}$
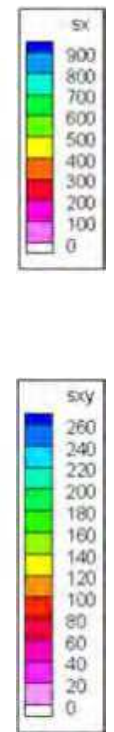

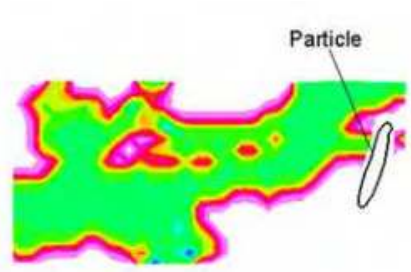

(b) $\sigma_{y}$

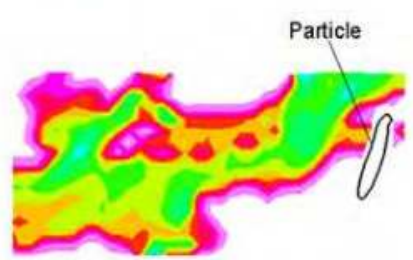

(d) $\bar{\sigma}$
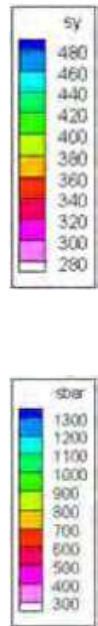

$20 \mu \mathrm{m}$

Fig. 12. Stress distribution in micro-cutting of Steel A

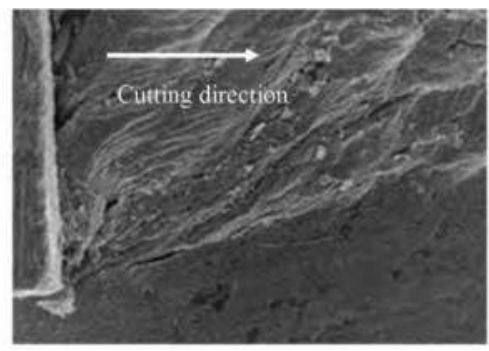

(a) SEM

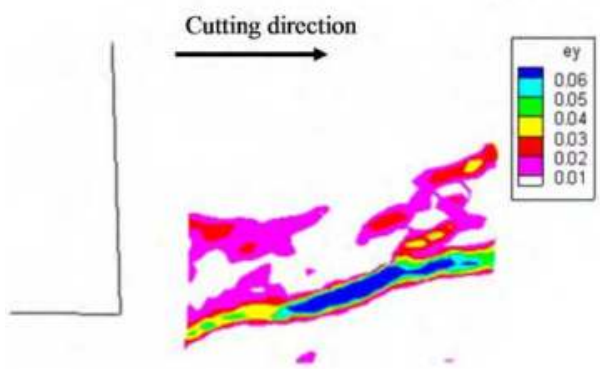

(c) $\mathrm{d} \varepsilon \mathrm{y}$

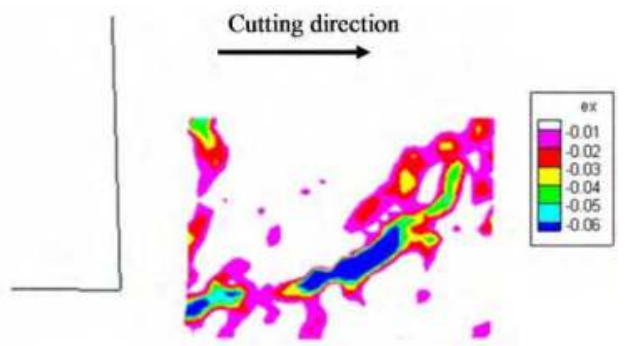

(b) $\mathrm{d} \varepsilon \mathrm{x}$

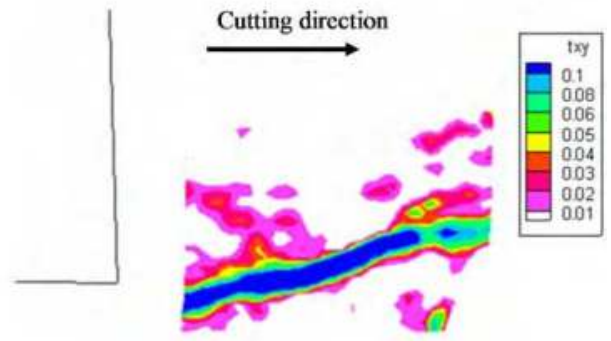

(d) $\mathrm{d} \nu \mathrm{xy}$

Fig. 13. SEM image and strain increase distribution in micro-cutting of Steel A 
The stress distribution was calculated from the strain increase distribution. Figure 14 shows the stress distribution in micro-cutting of the Steel B. As the Steel B had long slender inclusions, the inclusion MnS broke into small pieces and the stress distributed along the shear plane. There is little stress concentration around the MnS.

Consequently, in the Steel A which has large spindle type MnS, the micro-crack is easily formed. As this micro-crack affects the breakage of a build-up edge (BUE) and chip, the BUE could not become big and the good finish surface roughness was gained in the Steel A. As shown in Fig. 15, large micro-crack affected the separation between the chip and the BUE.
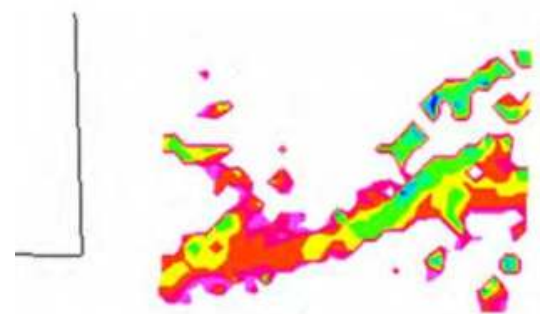

(a) $\sigma_{\mathrm{x}}$

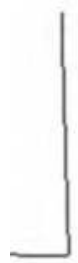

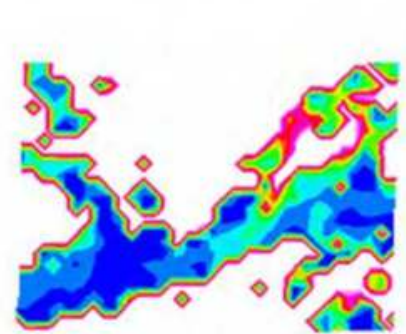

(c) $\tau \mathrm{xy}$
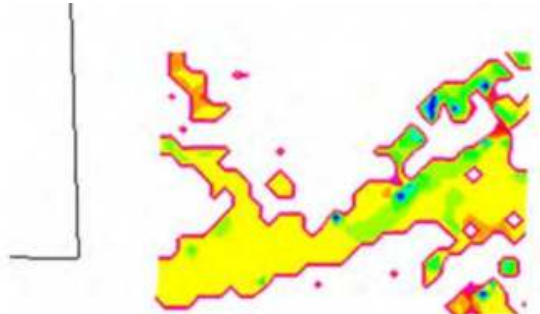

(b) $\sigma_{\mathrm{y}}$
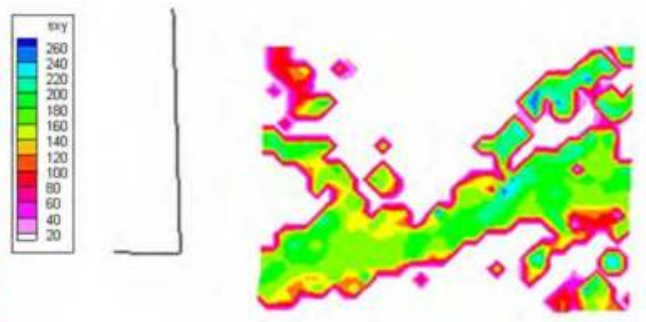

(d) $\bar{\sigma}$
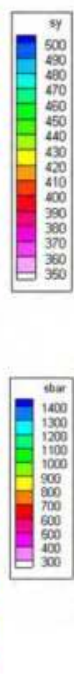

$20 \mu \mathrm{m}$

Fig. 14. Stress distribution in micro-cutting of Steel A

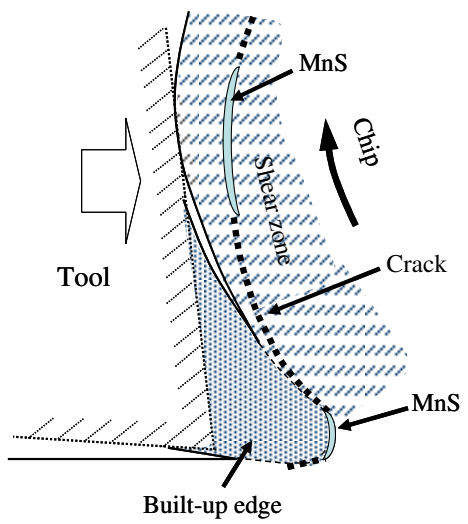

Fig. 15. Effect of spindle-type MnS to suppress BUE growth in the vicinity of BUE 


\subsection{Quick stop test during turning.}

A quick stop experiment during turning was carried out with the quick stop system which was attached to a conventional lathe. Figure 16 shows the equipment of the quick stop test. The tool was rotated down at the moment when pulling a pin which fixed the tool and the cutting state was stopped quickly. The deformation behavior around the shear zone was observed from the workpiece with a chip. The cutting speed was $62 \mathrm{~m} / \mathrm{min}$ and the depth of cut was $0.2 \mathrm{~mm}$. Table 5 shows the cutting conditions.

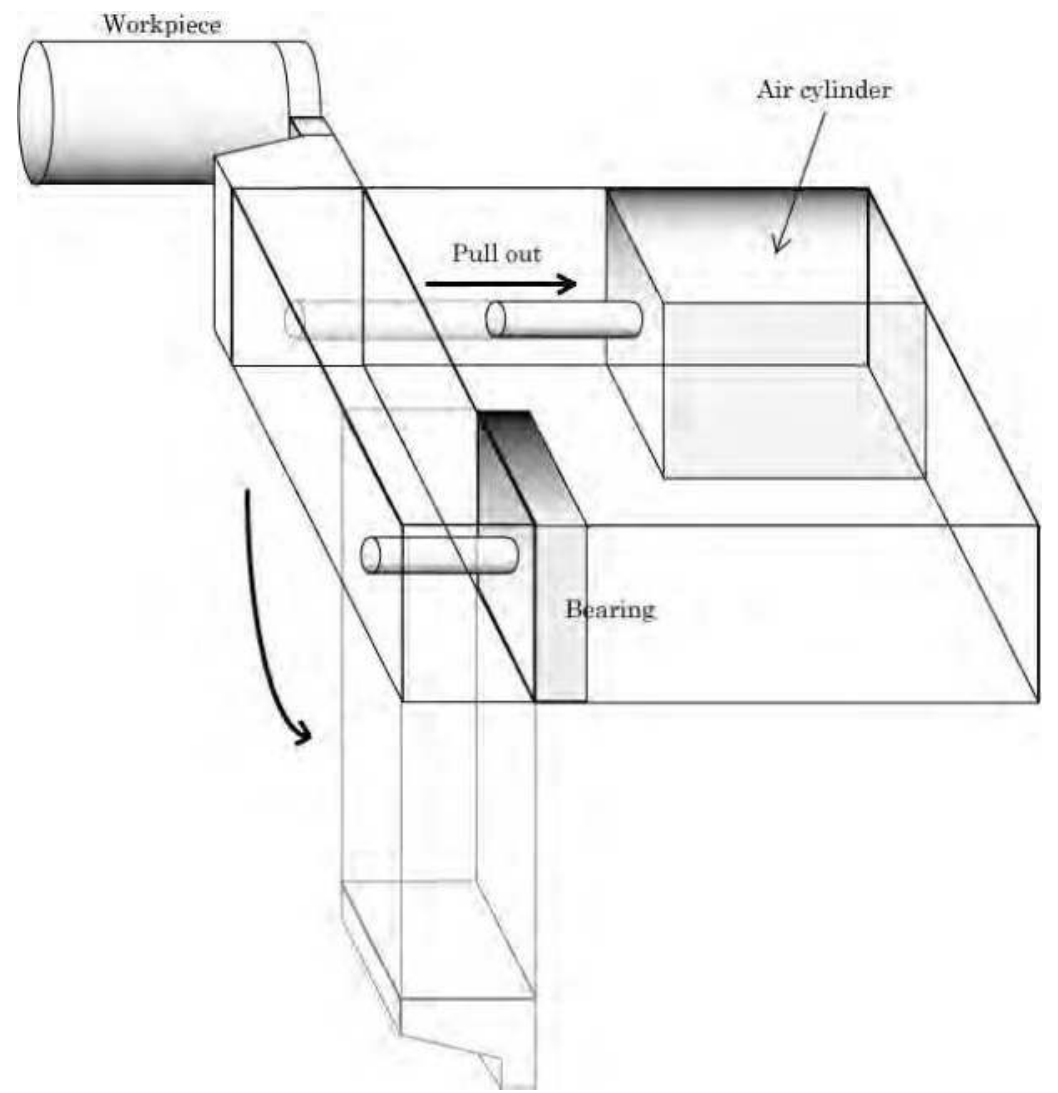

Fig. 16. Equipment of quick stop test

\begin{tabular}{|c|c|}
\hline Cutting speed & $62 \mathrm{~m} / \mathrm{min}$ \\
\hline Depth of cut & $0.2 \mathrm{~mm}$ \\
\hline Tool & Cemented carbide P10 \\
\hline Rake angle & $20^{\circ}$ \\
\hline Clearance angle & $6^{\circ}$ \\
\hline
\end{tabular}

Table 5. Cutting condition in quick stop test 


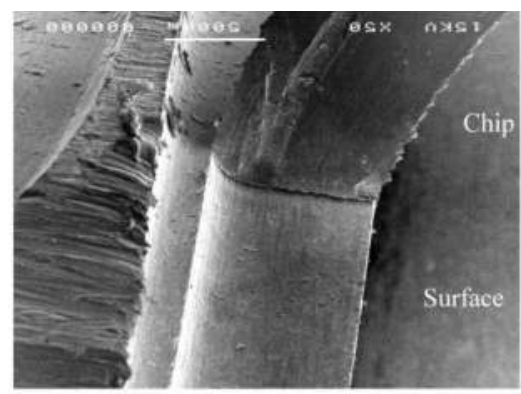

$500 \mu \mathrm{m}$

(a) Steel A

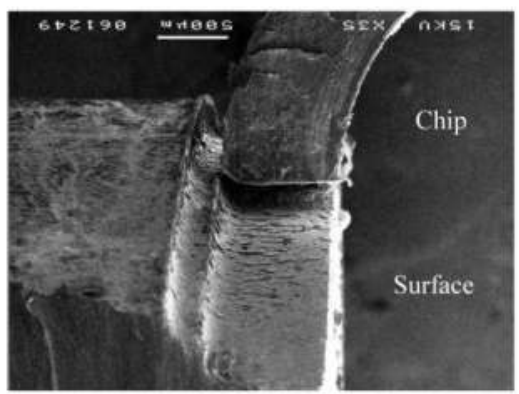

$500 \mu \mathrm{m}$

(c) Steel B

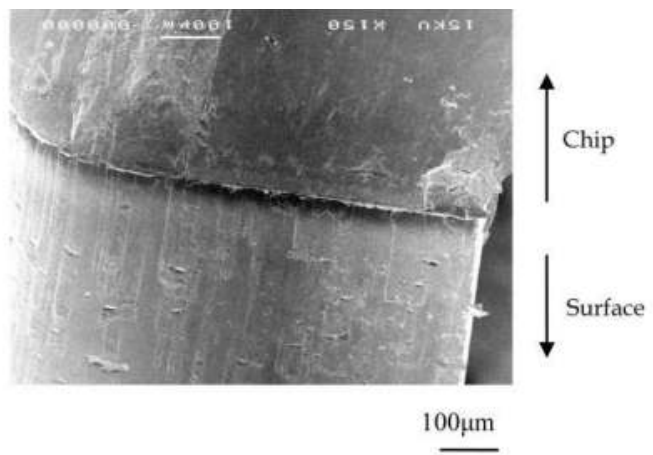

(b) Steel A

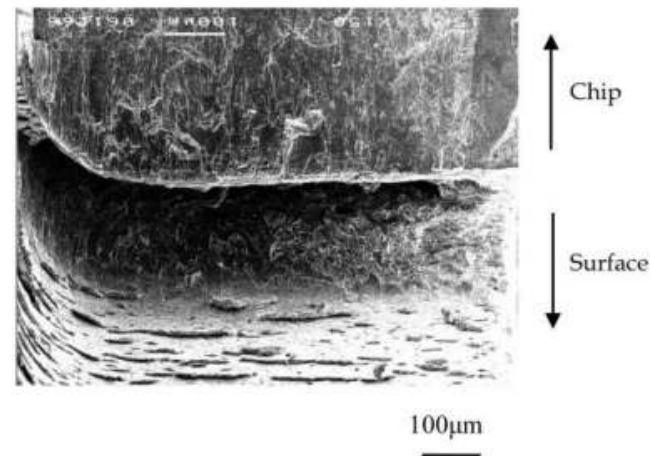

(d) Steel B

Fig. 17. Chip and finish surface in quick stop test

In quick stop test, the chips in the vicinity of the tool face and machined surface was observed as shown in Fig. 17. In case of the Steel A which contains large spindle shaped inclusions, the BUE could not be found. And machined surface had good surface roughness. In case of the Steel B which contains small slender inclusions, the BUE could be found on the rake face of the chip. There were many tears on the machined surface. The BUE partially separated and they leave on the machined surface. As a result, the surface roughness became bad. In this experiment, it was clear that the larger inclusions could reduce the formation of the BUE.

\section{Conclusions}

The main results obtained are as follows.

1. In machining of sulfurized free-machining, some inclusions creates voids around them, some break to several pieces depending on their conditions around the shear zone.

2. The larger inclusions can reduce the formation of the BUE. 


\section{References}

Akazawa, T., Free cutting steels contributing to industry, Journal of Special Steel, Vol.46, No.5 (May 1997), pp.6-10.

Araki, T., Yamamoto, S., Machinability of Steel and Metallugical Factors, Iron and Steel, Vol.57, No.13 (Nov. 1971), pp.1912-1932.

Iwata, K., Ueda, K., Shibasaka, T, Study on Micro-machining Mechanics Based on DirectSEM Observation, Journal of Japan Society of Precision Engineering, Vol. 43, No.3 (1977) pp.311-317.

Katayama, S., Toda, M., Hashimura, M., Growing Model of Build-up Edge in Relation to Inhomogeneities of Steel Microstructure, Journal of Japan Society of Precision Engineering, Vol. 62, No. 9 (1996) pp.1345-1349.

Maekawa, K., Kubo, A., Kitagawa, T., MachinabilityAnalysis of Free-machining Steel, Journal of Japan Society of Precision Engineering, Vol. 57, No. 12 (1991) pp.2193-2198.

Narutaki, N., Yamane, Y., Usuki, H., Yan, B., Kuwana, T., Machinability of Resulfurized Steels under High Cutting Speed, Journal of Japan Society for Precision Engineering, Vol.53, No.3 (March 1987), pp.455-466.

Raffel, M., Willert, C.E., Kompenhaus J., (2000) Particle Image Velocimetry, Springer, ISBN 3-540-63683-8 New York.

Usui, E., (1990) Modern Cutting Theory (1st), Kyouritsu Shuppan, ISBN 4-320-08054-8, Tokyo.

Usui, E., Obikawa, T., Shirakashi, T., Embrittle Action of Free-machining Additives, Japan Society for Precision Engineering, Vol.46, No.7 (July 1980), pp.849-855.

Yaguchi, H., Effect of MnS Inclusion Size on Machinability of Low-Carbon Leaded Resulfurized Free-Maching Steel, Journal of Applied Metalworking Vol. 4, No. 3 (1986) pp.214-220.

Yaguchi, H., Effect of soft assitives (Pb, Bi) on formation of Build-up edge, Journal of Material Science Technology, No. 4, (1988) pp.926-932.

Yaguchi, H., The Role of Liquid Metal Embrittlement on the Chip Disposability of Steel, Iron and Steel Vol.77, No.5 (May 1991), pp.683-690. 


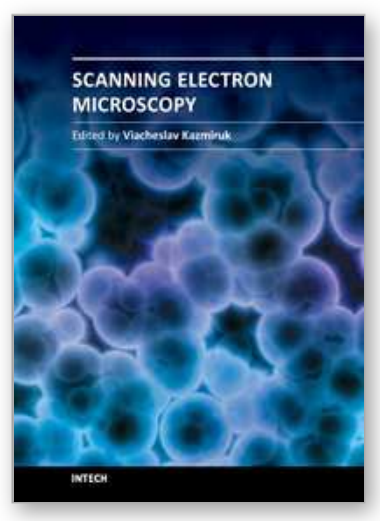

\author{
Scanning Electron Microscopy \\ Edited by Dr. Viacheslav Kazmiruk
}

ISBN 978-953-51-0092-8

Hard cover, 830 pages

Publisher InTech

Published online 09, March, 2012

Published in print edition March, 2012

Today, an individual would be hard-pressed to find any science field that does not employ methods and instruments based on the use of fine focused electron and ion beams. Well instrumented and supplemented with advanced methods and techniques, SEMs provide possibilities not only of surface imaging but quantitative measurement of object topologies, local electrophysical characteristics of semiconductor structures and performing elemental analysis. Moreover, a fine focused e-beam is widely used for the creation of micro and nanostructures. The book's approach covers both theoretical and practical issues related to scanning electron microscopy. The book has 41 chapters, divided into six sections: Instrumentation, Methodology, Biology, Medicine, Material Science, Nanostructured Materials for Electronic Industry, Thin Films, Membranes, Ceramic, Geoscience, and Mineralogy. Each chapter, written by different authors, is a complete work which presupposes that readers have some background knowledge on the subject.

\title{
How to reference
}

In order to correctly reference this scholarly work, feel free to copy and paste the following:

Junsuke Fujiwara (2012). Cutting Mechanism of Sulfurized Free-Machining Steel, Scanning Electron Microscopy, Dr. Viacheslav Kazmiruk (Ed.), ISBN: 978-953-51-0092-8, InTech, Available from: http://www.intechopen.com/books/scanning-electron-microscopy/cutting-mechanism-of-sulfurized-freemachining-steel

\section{INTECH}

open science | open minds

\author{
InTech Europe \\ University Campus STeP Ri \\ Slavka Krautzeka 83/A \\ 51000 Rijeka, Croatia \\ Phone: +385 (51) 770447 \\ Fax: +385 (51) 686166 \\ www.intechopen.com
}

\author{
InTech China \\ Unit 405, Office Block, Hotel Equatorial Shanghai \\ No.65, Yan An Road (West), Shanghai, 200040, China \\ 中国上海市延安西路65号上海国际贵都大饭店办公楼 405 单元 \\ Phone: +86-21-62489820 \\ Fax: $+86-21-62489821$
}


(C) 2012 The Author(s). Licensee IntechOpen. This is an open access article distributed under the terms of the Creative Commons Attribution 3.0 License, which permits unrestricted use, distribution, and reproduction in any medium, provided the original work is properly cited. 